\title{
Е.Б. Бесолова
}

Северо-Осетинский институт гуманитарных и социальных исследований им. В.И. Абаева Владикавказского научного иентра РАН

$$
\text { и Правительства РСО - Алания }
$$

\section{О форме мировосприятия Нартов (на материале сказания «Гибель семьи Сырдона»)}

Аннотация: В работе рассматривается особый способ мировосприятия Нартов, идентичный народно-поэтическому.

The paper deals with a special way of the Narts' world-view identical with folk poetry.

Ключевые слова: божество-андрогин, фандыр, языческая символика, десница, миротворение.

Androgynous deity, fandyr, pagan symbolism, right hand, peacemaking.

УДК: 398.22 (470.65)

Контактная информаџия: Владикавказ, просп. Мира, 10. СОИГИСИ ВНЦ РАН. Тел. (8672) 531327. E-mail: elenabesolova@ mail.ru.

В статье с учетом древнейших мифопоэтических представлений предпринята попытка воссоздать языческую символику предметов, культовых действий, обрядов и показать отражение этой символики в языке, ибо «символические знаки языка существуют не для того, чтобы обозначать что-либо, существующее помимо них. Напротив, бытие выводится из значения этих символов» [Кассисер, 1923, т. 1.1, c. 42$]$.

Магическая ментальность особенно ярко проявляется в эволюции значения. Переходы значений слов в полной мере отражают обычаи, верования и способы мышления древнего слова, которое на наиболее ранних этапах его существования отождествляло всё живое и неживое, придавало огромное значение аналогии, оперировало разного рода магическими образами и символами. И это вполне объяснимо: первобытное мировосприятие не знало отвлеченных понятий, ему была свойственна очень условная система пониманий объективной действительности, хотя уже тогда и в то же время человек отождествлял вещь и процесс, вещь и ее свойство [Фрейденберг, 1979, с. 19-21].

Анализ мифов, как известно, есть средство выявления первичных структур сознания, и с этих позиций мы попытаемся «прочитать» отрывок из нартских сказаний о создании фженыра - двенадцатиструнной арфы осетин.

Несмотря на множество посвященных этому отрывку работ, его интерпретация остается, по нашему разумению, концептуально неясной: не использовано прочтение текста сказания «Гибель семьи Сырдона» в соответствии с той формой мировосприятия, которая по ряду параметров близка к поэтическому мировосприятию, наблюдающемуся в народном творчестве. Основание для подобного рассмотрения дает наличие большого количества неосознанных, эмоциональноволевых элементов, типичных для мифопоэтического восприятия. Единство эмоционально-волевого и образного компонентов, сочетание сакрального и профанного, реального и чудесного, универсального и изменчивого, разделение которых 
происходит на более позднем уровне, когда возникает и «понимание», и анализ [Пашинина, 2001, с. 29] - вот черты, присущие данному способу мировосприятия.

Сюжет сказания таков. Сырдон в голодный год похитил и зарезал упитанную корову Хамыца. В то время, когда мясо коровы варилось в котле у него дома, Сырдон явился на ныхас (место, где мужчины проводили свое свободное время) и стал подтрунивать над Хамыцем. Тот, заподозрив неладное, решил пробраться в дом Сырдона. С трудом поймал его собаку и, привязав к ее ноге нить, проник в его жилище. Хамыц застал странную картину. В котле варилось мясо коровы, тут же лежала ее голова, а вокруг котла сидели сыновья Сырдона, причем в одних версиях - их было трое, в других - семеро. Поняв, что к пропаже коровы причастен Сырдон, Хамыц в бешенстве, в отместку, порубил его детей и бросил в котел, где варилось мясо его коровы. Обеспокоенный отсутствием Хамыца, Сырдон заторопился домой. Вынимая из котла мясо коровы, с ужасом узнавал части тел своих детей. Потрясенный гибелью сыновей, Сырдон собирает из костей руки (десницы) старшего сына фандыр (арфу), натягивает струны из жил убитых сыновей (вариант - волосы из седых кос покойной матери), и в звуках арфы изливает свое горе:

... Сырдон собрал куски трёх мёртвых тел,

В последний раз на них он посмотрел.

Очажный камень стал плитой могиль,

Детей своих под камнем схоронил.

Но одного из сыновей десницу

Себе оставил, чтоб всю жизнь томиться

За то, что сам обрёк детей на гибель.

И на деснице мёртвой, на изгибе,

От кости лучевой $\partial о$ плечевой,

Из кос покойной матери родной

Он натянул двенадцать волосков.

И был фандыр излюбленный готов,

Фандыр из кости собственного сына,

Где струны - материнские седины.

[Нарты, 1957, с.219-225]

Или же: «... Взял он (Сырдон - Е.Б.) кисть руки старшего сына и натянул на неё двенадцать звонких струн, а струны те были из жил, что несли кровь к сердиам его сыновей...» [Осетинские нартские сказания, 1948, с. 209].

Музыкальные инструменты, как известно, - медиаторы, проецирующие космическую музыку в земное пространство. Среди них - и традиционный дыууадсестсенон фсендыр, который, по определению Ф.Ш. Алборова, является разновидностью небольшой угловой (в форме треугольника) apфbl с двенадиятью струнами, изготовлявшимися из конского волоса [Алборов, 2004, с. 148].

Прекрасной и, думаем, достаточно весомой иллюстрацией к нашей статье является картина основоположника осетинской художественной школы Махарбека Сафаровича Туганова «Нарт Сырдон» («Осетинский фандыр»).

В соответствии с мифопоэтическим восприятием предков осетин мифоритуал о создании фандыра-арфы есть, на наш взгляд, представление о расчленении Хаоса. Во многих традициях свидетелями миротворения являются жертвенные животные. С верхом соотносятся птицы, с серединой - копытные животные, с низом - пресмыкающиеся, земноводные, хищники. Их распределение по миру связано с трехчастной структурой мирового древа [Королев, 2003, с. 147].

Жертвоприношение, по мнению язычников, вносило «порядок, гармонию» в человеческую жизнь. Названия жертвенных животных соотносились со значением «музыка», а она олицетворяла космическую гармонию, выраженную в звуке 
(голос), сокровенном знании об устройстве мироздания. Космическая музыка связывала воедино макро- и микрокосм - мироздание и человека, она пронизывала небесные сферы и управляла временем. Музыкой создан мир, который представлялся и как гармония и природа звуков, и как энергия, объединяющая и упорядочивающая вселенную. Она вплеталась в первоначальный хаос и творила из него космос [Закс, 1929].

Корова и другие парнокопытные индоевропейцами в древности считались божествами, символами святости; название коровы табуировалось понятием «духа», а также названием животных и предметов, вмещавших в себя дух (душу). Она воплощала верхний мир - Небо и символизировала плодородие, благосостояние, изобилие, являлась олицетворением Вселенной, Космоса. Если в мифологии сакральная корова, участвующая в миротворении, является символом космогонической целостности, то получается, что корова Хамыца в эпосе воплощает мироздание Нартов, нартский космос.

Стельная корова в мифологии индоевропейцев олицетворяет женские животворящие и питающие силы Земли. Но корова Хамыца, которую украл Сырдон, не стельна, в течение семи лет бесплодна [Нарты, 1989, с. 206]. Бесплодность здесь является признаком ее мужской сущности. Но, заметим, что и сакральное значение символа мироустройства и божественности числа Неба «семь» в словосочетании семь лет бесплодна также соотносится со значением «мужская суть». Как видим, «жертвы богам небесным» приносят «числом нечётным, а земным чётнылм». Четные и нечетные числа выражают свойственное мифопоэтической традиции противопоставление земного и небесного, женского и мужского, левого и правого, низа и верха. По Пифагору, «всё в мире есть числа», и числа - божественны. Они сила, поддерживающая вечное постоянство Космоса, космическую гармонию, и поскольку числа олицетворяют правило, порядок, музыку, то всё в мире устроено по канонам, упорядоченно и музыкально [Закс, 1929; Sachs, 1930].

...Он (Сырдон) натянул двенадцать волосков... (двенадиать звонких струн из жил, что несли кровь к сердияам его сыновей...).

Человеческое тело, как известно, древними индоевропейцами толковалось как воспроизведение структуры мироздания из 12 частей, где отдельные его части обладали собственной символикой. Рождение Нового мира, Космоса могло произойти лишь после разделения на части аморфного тела существа. Из этих компонентов, как свидетельствуют космогонические мифы, возникли разные части космоса. В древности число двенадцать считалось полным и совершенным, оно управляет пространством и временем и символизирует Порядок и Добро.

Boлосы, как и жилы, являются символом и вместилищем жизненной силы, огня и божественной силы, питающей себя самое, и «поскольку волосы растут на «верхушке» человеческого тела, они символизируют духовные силы, их можно соотнести с символикой воды» [Кирло, 2010, с. 101].

Символическое значение apфbl, древнейшего музыкального струнного щипкового инструмента, - связь (мост) неба и земли, мистическая лестница и циклическое развитие мира, а также олицетворение упорядоченного мироздания. Изображает переход в другой мир, иногда представляется как воплощение чистой идеи звука - носителя напряжения и страдания. Понимается арфа и как символ мировой гармонии и гармонического единства неба и земли, а также отзывчивости и чуткости к земной и небесной жизни [Королев, 2003, с. 322].

Арфа бывает лукообразной и угловой, двенадцатиструнная фандыр-арфа нартов - угловая, имеет форму треугольника, т. е. космической фигуры, возникшей из хаоса. Треугольник, как и число «три», является средоточием целостности и имеет содержанием значения «созидание», «творчество». Арфа является символом «жизни - смерти - новой жизни». 


\section{...И на деснице мёртвой, на изгибе, \\ $O m$ кости лучевой $\partial o$ плечевой...}

Кость, по поверьям древних индоевропейцев, считалась вместилищем жизни и тесно связанной с ней смерти, а также местом пребывания душ. Пространство, очищенное от мяса (плоти), от кости лучевой до плечевой - мировое древо, отделявщее небо от земли.

Правая рука - десница - обладает положительной семантикой, это символ духовного влияния, Небесного Пути. «Основа *deks-, - пишет В.И. Абаев, - выступает в индоевропейских языках в двух, тесно связанных между собою, значениях: с одной стороны, «правый», ( $\rightarrow$ «равая рука», «правая сторона»), с другой - «искусныци»...

Известно, что «правая сторона» с давних пор ассоциируется со счастьем, удачей, искусством... («правая рука» = «искусная рука»)». Но в осетинском языке основа *deks- представлена как deesny/ dcesni «ведун» [Абаев, т. 1, 1958, с. 360], т. е. «чародей, колдун», коим является Сырдон.

Космогоническая целостность отражалась, как известно, в единстве противоположностей. На уровне человека наиболее ярко это представлено в андрогине, символе целостной личности, мудрости и бессмертия.

Считается, что андрогинизм является свойством древних богов [Блаватская, 1998, с. 107]. По мнению В.И. Абаева, образ Сырдона «связан с древнейшей частью эпоса, ...однако, с течением времени, мифологические черты в его образе оказались совершенно заслоненными массой бытовых мотивов» [Абаев, 1945, c. 72]. Таким божеством-андрогином можно предположить Сырдона.

Первосущество, будучи расчлененным на части, превращается в арфу. Арфа, выраставшая из мертвых останков божества-коровы и сыновей Сырдона, уподобилась «скелету» бога, о чем дополнительно говорит и семантика «трёхногости» инструмента, или «троичности» [Топоров, 1977] числа «3»- «три мёртвых тела» или «куски трёх мёртвых тел».

В древности иранцами, чтобы не осквернять четыре стихии, труп выставлялся на солнце до полного очищения от плоти костей. Затем кости собирали в специальное хранилище, потому что с ними связывалась надежда на возрождение покойника.

«Грабить» плоть божества могли только хищные птицы и звери (ср.: этимология имени Сырдон / Сирдон от сырд / сирд «зверь») [Абаев, т. 3, 1979, с. 208]. К примеру, мёртвые тела зороастрийцев пожирали хищные птицы. В далеком прошлом этот обряд растерзания зверями и птицами почитался божественным актом и гарантировал мертвым возрождение.

В котле мыслятся останки умершего бога, перевариваемые в нем, как в утробе богини-коровы. Именно этот обряд глубокой древности гарантировал мертвым воскрешение. Ритуал варки (т.е. обновления) в котле хорошо известен в мифологии как обряд омоложения; например, вариться в котле, превращаясь из старухи в юную девушку или из старика в юношу.

Таким образом, душа умершего в сказании о появления фандыра (арфы) возрождалась путем андрогинизма, восстановления двуполого первосущества, каким был Сырдон.

Сырдон, знавший ритуал смерти-возрождения, обладал особым могуществом. В архаической форме герой имел две ипостаси в нартском эпосе - оборотня (становился стариком, старухой, молодой женщиной и пр.) и колдуна.

В древнейшем цикле сказаний о Сырдоне наблюдается его связь с рыбами: он - сын владыки вод, Гатага. Его отношение к воде свидетельствует о том, что герой связан с ритуалом смерти-рождения. Сыновья божества воды, внуки владыки вод, также символизируют собой первичный водный хаос. Налицо параллелизм съедаемых жертв - коровы-божества и сыновей божества воды. Именно 
Сырдон ограбил плоть божеств, превратив «скелет» жертв в мировое древо, отделявшее небо от земли.

Предполагаем, что Сырдон мог превращаться в бога-рыбу. Это не проявляется в текстах сказаний, но подспудно скрывается в его поступках: в его свойстве появляться и исчезать когда и где угодно; в его связи с подземным миром.

Сыновья Сырдона, внуки бога-реки, были погребены отцом под очажнымм камнем - в этом прочитывается нами противопоставление водного Хаоса творческому Огню.

Жилище Сырдона - подземный дом-лабиринт - ритуально нечисто. В нем, как в хтоническом мире, царит мрак, и вошедший в него с востока, где был вход, попадал в царство запада, смерти.

Лабиринт семантически связывается с подземным миром и небом. Выход из него сложен и требует осмысления. Спиралевидные дорожки выступают как средство очищения, пройдя через которые герой приобретает возможность выхода из лабиринта, обретая после катарсиса силы для дальнейших испытаний.

Но лабиринт есть также путешествие от смерти к рождению.

Ритуальное его значение - место посвящения (инищиащии: мы наблюдаем процесс перехода Сырдона из подземного состояния в земное). Главная функция, по М. Элиаде, - охрана центра. Лабиринт охраняется Сырдоном-жрецом, живущим в самом его центре; наш герой-демиург - владыка и судьба лабиринтахрама, связующего звена между возвышенным (Небо) и низменным (Земля).

Центр, середина индоевропейцами в древности считалась символом сверхъестественной силы, бессмертия, да и понятие бога соотносилось с этим понятием. Образ спирали (изображение путешествия души по лабиринтам загробного мира) также связан с символикой лабиринта. Символы середины, центра, первого человека, бессмертия, выхода из лабиринта связываются именно с понятием андрогинизма.

В подземном жилище Сырдона обитала и собака-сука. Она ассоциируется в мифопоэтическом сознании с землей, водой, луной; собака - символ смерти и загробного мира. Ее отношение к воде свидетельствует о том, что она связана с ритуалом смерти-возрождения. Собака-сука является к тому же еще и символом жреческого ремесла.

Наш герой - и зверь, разграбивший плоть, и божество-андрогин, и жрец, превративший «скелет» жертвы в мировое древо, отделявшее небо от земли.

В сказании о появлении фандыра налицо мотив первооткрывателя: каждое ремесло, как положено, должно иметь своего первооткрывателя. Сырдон - первый создатель осетинской музыки, символизирующей порядок и гармонию творения, первопричиной которого был Звук. Проявлением звука является голос. Извлеченная из правой руки, т.е. деснищы, сына песня-плач Сырдона связана с клокотанием варящейся плоти в котле. Символически это и есть ритуал рождения музыки жизни, голоса жизни через смерть. Локтевая и плечевая кости, опустошенные от мозга костей и плоти, исторгали музыку смерти (как духовой инструмент). Арфа (как струнный инструмент) производила музыку жизни, вызывавшую наращение плоти, натяжение жил и суставов, восстановление всей духовной конституции бога (за счет жил).

Сырдон достиг определенной степени осознания своей принадлежности к нартской общности, которой еще не был принят, но уже уяснил для себя смысл этой интеграции, ее движущие силы. Первотворение Звука оказалось для него спасительным актом: «Плач Сирдона и его игра на арфе потрясли даже суровых Нартов. Они простили ему все его прошлые деяния и приняли в свою среду как равноправного» [Абаев, 1945, с. 72].

В данном этюде мы попытались восстановить то, что «образ Сирдона потерял с мифологической стороны», потому что время шло, и они «оказались совер- 
шенно заслоненными массой бытовых, частью анекдотических мотивов, собиравшихся вокруг его личности» [Там же].

Как видим из анализа, мифология и мифопоэтика предполагают специфический способ или своеобразную форму мировосприятия, потому что миф не может зависеть от канонов целесообразности, разумности, всего того, что присуще научно-логическому мышлению и миропредставлению. При всей устойчивости и традиционности миф обладает особого рода изменчивостью, которая является причиной его неопределимости, непонятности и допускает соотнесение мифа и эпоса на предмет изыскания мифологических черт в религиозном и научном мышлении. Исходя из того, что самобытность мифопоэтического мировосприятия является важнейшим таинством мифа, а «отголоски мифопоэтики встречаются во все времена и в любых культурах», на сегодня выявление и интерпретация специфики мифопоэтического мировосприятия крайне актуальны, в силу даже того, что она проявляется на всех стадиях развития общества.

По В.Н. Топорову, общий контекст ритуала реализуется «в максимальной полноте и органичности содержащихся в нем потенций... в мифопоэтическую или космологическую эпоху, определяемую соответствующим типом мировоззрения, миропонимания, точнее - миропереживания, переживания мира в процессе контактов с ним, реализующихся, прежде всего, через деятельность - как «нагляднопрактическую, так и «теоретическую...» [Топоров, 1988, с. 9].

\section{Литература}

Абаев В.И. Историко-этимологический словарь осетинского языка. Л.; М., 1958. Т. 1.

Абаев В.И. Историко-этимологический словарь осетинского языка. Л., 1979. T. 3 .

Абаев В.И. Нартовский эпос // Известия Северо-Осетинского научноисследовательского института. Т. Х. Вып. І. Дзауджикау, 1945.

Алборов Ф.Ш. Музыкальная культура Осетии. Владикавказ, 2004.

Блаватская Е.П. Тайная доктрина: В 2-х т. СПб., 1998.

Закс К. Дух и становление музыкальных инструментов. М., 1929.

Кирло Хуан. Словарь символов / Пер. с англ. Ф.С. Капицы, Т.Н. Колядич. М., 2010.

Королев К. Энциклопедия символов, знаков, эмблем. М.; СПб., 2003.

Нарты: Эпос осетинского народа. М., 1957.

Нарты: Осетинский героический эпос. М., 1989. Кн. 2.

Осетинские нартские сказания. Дзауджикау, 1948.

Пашинина Д. Мифопоэтическое восприятие: закон участного внимания // Международные чтения по теории, истории и философии культуры: Интеллект, воображение, интуиция. СПб., 2001.

Топоров В.Н. К семантике троичности // Этимология, 1977. М., 1978.

Топоров В.Н. О ритуале. Введение в проблематику //Архаический ритуал в фольклорных и раннелитературных памятниках. М., 1988.

Фрейденберг О.М. Миф и литература древности. М., 1979.

Cassirer E. Philosophie der Symbolischeh Formen. Berlin, 1923. T. 1.1.

Sachs C. Vergleichende Musikwissenschaft in ihren Grundzugen. Lpz., 1930. 